\title{
Moscow Conceptualism through Collective and Private Memory. The Archive as an Artistic Self-historicising Practice in Vadim Zakharov
}

\author{
Alessandra FRANETOVICH \\ University of Florence, Pisa and Siena, PhD Student in Art History \\ E-mail: alessandra.franetovich@unifi.it
}

\begin{abstract}
In an era characterised by the growing tension between local and global, the multiple activities acted by the artist Vadim Zakharov offer an important case study to investigate critically the relationship between artists and the art institutions at the time of the Global Art History. Artist, archivist, collector and editor in the frame of Moscow Conceptualism, since the end of the 1970s up to today, Zakharov embodies the figure of the "artist as institution" in the attempt to reach his artistic autonomy. This text introduces to his expansion of the archival attitude typical of Moscow conceptualism, a Soviet unofficial art movement developed in the marginal, underground, and self-referential context in the capital of USSR since the 1970s. Due to its transnationality, Zakharov's story gives the opportunity to trace parallels, comparisons and differences to what happened next, when he moved in Germany in 1989, after the fall of USSR, and with the appearance of the new labels of "post-Soviet" and "Russian contemporary art". Within this sociohistorical framework, he joined a more cosmopolitan artistic scene, enlarging his archival practices with the aim to self-institutionalize and self-historicize his own artistic practices and the circle of Moscow Conceptualism in an international scene.
\end{abstract}

Keywords: Vadim Zakharov, Moscow Conceptualism, Russian Contemporary Art, Contemporary Art, Global Art History, Archival fever.

Rezumat: Într-o epocă caracterizată de tensiunea tot mai mare dintre local şi global, multiplele activități desfăşurate de artistul Vadim Zakharov oferă un studiu de caz important pentru investigarea critică a relației dintre artişti şi instituțiile de artă din timpul istoriei globale a artei. Artist, arhivist, colecționar şi editor în cadrul conceptualismului moscovit, de la sfârşitul anilor 1970 şi până în prezent, Zakharov întruchipează figura „artistului ca instituție” în încercarea de a-şi atinge autonomia artistică. Acest text introduce expansiunea pe care artistul o aduce atitudinii arhivistice tipice conceptualismului moscovit, o mişcare artistică neoficială sovietică dezvoltată în contextul marginal, underground şi auto-referențial din capitala URSS încă din anii 1970. Datorită transnaționalității sale, povestea lui Zakharov oferă posibilitatea de a urmări paralele, comparații şi diferențe cu ceea ce s-a 
întâmplat mai departe, când s-a mutat în Germania în 1989, după căderea URSS şi odată cu apariția noilor etichete de „post-sovietic" şi „Arta contemporană rusă". În acest cadru socio-istoric, el s-a alăturat unei scene artistice mai cosmopolite, lărgându-şi practicile arhivistice cu scopul de a se auto-instituționaliza şi de a auto-istoriciza propriile practici artistice şi cercul conceptualismului moscovit într-o scenă internațională.

Cuvinte cheie: Vadim Zakharov, Conceptualismul de la Moscova, Arta contemporană rusă, Arta contemporană, Istoria globală a artei, Febra arhivistică.

In April 2018 the artist Vadim Zakharov conceived and realised the installation titled Moscow Conceptualism presented by Vadim Zakharov. Terms shown in Figure n.1, for the exhibition Hello World. Revision einer Sammlung held at the Hamburger Bahnhof in Berlin. Curated by an international committee, the exhibition put together and displayed more than 250 artists and 700 pieces, such as artworks and historical documents loaned from different museum collections in Germany and from other countries. The project aimed to reflect, with a retrospective look, the character of the collection that is interpreted as «the foundation of a museum, which itself is shaped by contingent political and cultural conditions», 1 focusing on the specific case of the Nationalgalerie in order to investigate the influence of German history and culture on the same museum's collection. This idea lies in the shift operated in last decades from the Western point of view to a more critical approach that aims to analyse and rebuild new canons towards Global Art History. The main question made by the curatorial team moved towards this direction saying «What would the collection be like today if a more cosmopolitan understanding of art had informed its beginnings?».2 The ambitious structure of Hello World. Revision einer Sammlung motivated the viewer to put his attention not only on single artworks but also on their interaction with the thematic areas that settled the exhibition itinerary, with the purpose of overcoming and reflecting about the underlying reasons that bring to the establishment of a museum, and consequently of a national cultural heritage. The exhibition path was composed of several sections, each

1 The exhibition opened on $28^{\text {th }}$ of April and closed on 26th of August 2018. Hello World. Revision einer Sammlung, (exhibition booklet, Berlin: Hamburger Bahnhof, 2018), p. 11.

2 Hello World. Revision einer Sammlung, p. 11.

Problem: the original text from the booklet is this: "What would the collection be like today had a more cosmopolitan understanding of art informed its beginnings?" but it looks like an incorrect translation therefore I changed it, however I feel this choice is not correct as I used punctuation for a quote. 
of them characterized by a geographical/geopolitical area and curated by specific curators with a strong expertise in the related topic. In the spotlight of this exhibition, there were the processes that take to the construction of Art History, as a field constantly in progress, and the role that art institutions hold in this procedure. This consideration opens to a broad and significant enquiry that goes beyond each specific research field and points towards the main matter, i.e. that each selection is a choice, and represents a stance and an act of responsibility, as well as an exercise of power that influence the construction of Art History. In an international context distinguished by what I interpret as an attempt of "institutional self-critique", Zakharov presented a new artwork dedicated to topics that have always characterized his multidisciplinary production as artist, archivist, collector, and editor of Moscow Conceptualism, such as self-historicization and self-institutionalisation. The work is composed by an open structure that replicates the form of a common black folder, but realised in increased dimensions, on which the title of the artwork is written on a white label glued on the front side. As the Figure n. 2 shows, on the floor there are numerous papers with the definitions taken from the Slovar' Terminov Moskovskoy Kontseptual'noy Shkoly [Dictionary of Terms of the Moscow Conceptual School]. The lexicon was published for the first time in 1999 as a contribution to the seventh issue of the magazine Pastor, and later in the same year as an independent volume edited by the artist Andrei Monastyrski. ${ }^{3}$ As a real dictionary, it collects numerous terms carefully selected because of their importance to understand the specificities of the artistic movement. Therefore, it is possible to find words used and invented by artists in relation to their own production, by the community, and by critics. As to the audience, it was allowed to collect the papers and bring them home, in the background of this work there was the desire to spread the knowledge of the group's activity, even if most of the terms' descriptions can easily seem cryptic to people external to the circle, due to their specifity and self-referentiality. During the opening, Zakharov performed dressed up as a gorilla acting the figure of the animal confined in a cage. Laying down on a side, close to a perishing banana peel and to a plastic shit, he breathed deeply looking depressed for his own existential condition. For his function and form, the folder can be interpreted as a cage in which the Russian artist compares himself to an exotic animal, imported from a distant and almost unknown land, of which he is a cultural agent in the international territory, but he still feels himself misunderstood, and isolated from the surrounding world. This feeling explains what the title of the artwork suggests, i.e. the artist's intention

3 Vadim Zakharov, ed., Pastor magazine, vol. 7, Köln, Pastor Zond Edition, 1999; Andrei Monastyrski, Slovar' Terminov Moskovskoy Kontseptual'noy Shkoly, Mockva, Ad Marginem, 1999. 


\section{Alessandra FRANETOVICH}

to avoid presenting only himself but the living condition shared by the entire circle of Moscow Conceptualism, showing himself as the spokesperson. His position could be assumed in accordance to the fact that he was invited to the exhibition by the director of MG+MSUM Ljubljana Zdenka Badovinac, who curated the section titled "Sites of Sustainability. Pavilions, Manifestos and Crypts" that hosted works of historical importance made by artists from Eastern Europe and Russia. It was actually the only one area that presented an extensive project about the "former East". Even inside an international exhibition hosted in the currently bigger museum of Contemporary Art in the capital of Germany, Zakharov's work was still presented as a part of that complex but specific geopolitical context. If this labelling is understandable from the critical perspective on which the exhibition was based and set up, yet the artist decided to underline his uncomfortable position as artist and archivist of Moscow Conceptualism, but even more to vindicate his role as a possible solver of a problematic that is still actual after many decades.

The idea of a Russian artist playing the role of the animal in a cage, reminds of the performance Dog House acted by the artist Oleg Kulik at the opening of the exhibition Interpol held in Sweden in March 1996. The exhibition was conceived as an exchange between Russian and Swedish artists, who were asked to invite other artists in order to work as co-authors and to occupy freely the exhibition space to create a «cacophony» that could give attention both to the sense of conflict and the necessity of co-operation among artists. Viktor Misiano, who curated the exhibition with Ian Äman, said that the outcome seemed to represent the coeval European socio-political situation. ${ }^{4}$ Ukrainian born Russian artist active in Moscow since the beginning of the 1990s, Kulik already realised this typology of performance. Nevertheless, this event went down in history because while he was playing the dog barking at the audience, naked, and chained, he bit an art critic and another spectator who ignored the written warnings glued on the floor. The artist was thus arrested and a trial on what can be done or not in the field of contemporary art, as well as what is properly art and what is nothing else than "hooliganism" started. In Kulik's words: «The dog emerged as a metaphor of the borderline state of the human being positioned between nature and the socium», 5 but beyond this universal condition, the artist declared that it involved also his personal experience of a Russian artist active in the cultural and political tensions existing between East and West. Apart from the several differences between these two artworks, above all the lack of interest in self-

\footnotetext{
4 Viktor Misiano, "Interpol: The Apology of Defeat", in Eda Čufer and Viktor Misiano, (eds.), Interpol: The Art Exhibition Which Divided East and West (Ljubljana \& Moscow: IRWIN and Moscow Art Magazine, 2000)

5 Irina Kulik, “Oleg Kulik: Artificial paradise”, Antennae, 8/2 (2007): 34.
} 
historicization and self-legitimization in Kulik and its more individualistic approach, both offer a critical view of the relation between artists coming from the marginal areas of the art system and the international Western centres. This raises the questions: "Why these two artists decided to act the animal in jail?" and "What has changed since then?».

The artwork by Zakharov displays a vision about the relationship between East and West developed by the artist during decades, a vision that follows a personal but also a collective story began at the end of the Seventies, when he joined the circle of Moscow conceptualism and so the experience of the unofficial Soviet art. This story runs in parallel with the historical events that lead to the decay of the Soviet Union and to the deep socio-political changes that happened after it. From a Western point of view, these decades involved the transition from a Soviet nonconformist art to an overhaul of artistic practices mostly interpreted as political dissidence, and then as an expression of a more general post-Soviet culture, commonly labelled with its political past.

For Moscow Conceptualists, the Seventies were marked by selfreflection, and by the correlated interest in the definition of their own artistic practices, as well as the growing attention in their own social and working condition. They started to consider how to call a collective movement composed of different small groups of artists but at the same time characterized by individual researches, and that, freed from any manifesto or norm that could influence their practices, recognized themselves around the concept that the idea of the artwork is more important than the object created. The relation between East and West played a fundamental role, as demonstrated by the attention to the "dematerialisation of art objects", theorised in the USA by Lucy Lippard ${ }^{6}$ and the choice to reuse the term "conceptualism". These elements prove the attention towards the AngloAmerican Conceptual art and the international art system, partially known by Moscow conceptual artists through the filter of illegally imported American and European art magazines, and art catalogues. Boris Groys originally used the name Moscow Conceptualism in his famous article published in 1979 on the first issue of the tamizdat magazine A-Ya, edited by the Russian sculptor Igor Shelkovskij who moved to Paris in 1976. Titled Moscow romantic conceptualism, the text presented for the first time to an international audience the outgoing of this artistic movement, defining it in connection with the international system. At the same time, he highlighted the authenticity of the artistic production qualifying it as "romantic" in relation to the word

${ }^{6}$ Lucy Lippard, Six Years: The Dematerialisation of the Art Object from 1966 to 1972, (New York: Praeger, 1973). 
duchovnost [spirituality] to convey a concept typical of Russian culture.7 Together with it, the self-reflective approach introduced by the performative practice of the group Kollektionyye Deystviya [Collective Actions], especially by the following process characterized by commentaries and reflection on the same artistic experiences. The observations were shared by participants, and then annotated in books later collected in volumes titled Poyezdki za Gorod [Trips out of town]. Such a practice contributed to create an atmosphere of exchange and a platform for discussion, hence it can be considered a forerunner of what was developed later. ${ }^{8}$

A consequence to this attentiveness in self-historicization and selfinstitutionalisation was the spreading of a common interest in the practice of archiving, that reached a pivotal point with the realisation of papki MANI [folders MANI]. It is explicative that together with the reference to the archive given by the use of archival folders, the term MANI was the acronym for Moskovskiy Arkhiv Novogo Iskusstva [Archive of the Moscow New Art] ${ }^{9}$ and was invented by Andrei Monastyrski and the poet and artist Lev Rubinstein. ${ }^{10}$ The project highlighted the centrality of the archive as a strategy, and in its premises lay the necessity to be active in collecting and sharing information about unofficial artists, to let their own awareness grow and to legitimate their own practice and poetics. Papki MANI was thus conceived as an artistic project connected to the samizdat [self-publishing] culture, in fact it is a collection of information and documents completely self-managed and self-published that involved tens of artists who contributed directly in the production process realising four issues between 1981 and 1982. Besides being an important experience in the process of awareness for the artists of the movement, MANI has been one of the first term that the conceptualists used to self-define themselves, consequently the term was included in the selection for Slovar' Terminov Moskovskoy Kontseptual'noy Shkoly [Dictionary of Terms of the Moscow Conceptual School]. ${ }^{11}$ Each issue was edited by different artists and published with a limited run of five self-produced but identical copies, because during Soviet time it was forbidden and dangerous to publish more.

\footnotetext{
7 Boris Groys, "Moscow romantic conceptualism”, A-YA, 1, (Paris: Elancourt, 1979).

8 The group was formed by Andrei Monastyrski together with Nikita Alekseev and Georgy Kiesewalter in 1976, later it was joined by the artist Elena Elagina, Igor Makarevich, Nikolai Panitkov, and the scholars Sergei Romashko and Sabine Hänsgen.

${ }^{9}$ For this point, it will be used the term MANI.

10 Alexandra Danilova and Elena Kuprina-Lyakhovich, "MANI: An Experiment in Modelling Cultural Space", Anti-Shows. APTART 1982-84, Margarita Tupitsyn, Victor Tupitsyn et al. (eds.), (London: Afterall, 2017) p. 232.

11 Andrei Monastyrski, Slovar' Terminov Moskovskoy Kontseptual'noy Shkoly [Dictionary of Terms of Moscow Conceptualist School] (Moscow: Ad Marginem, 1999).
} 
Moreover, technically speaking, it was the limit number of pages that was possible to realise typing with a carbon copy leaf.

The volume was composed by a self-produced cardboard folder in which every participant artist was invited to put inside his contribution that was contained in a green common envelope with his name written on a small white label glued on it. Every envelope content differed from the others, however in most of them, the artists inserted photographs of their own artworks and biographical and/or explanatory texts. In sporadic cases, artists included artworks conceived for the specific format. The first volume was edited and published by Monastyrski who stated: «It wasn't entertainment but research and contemplation, folder MANI is a catalogue on that period that shows what was happening in that moment». ${ }^{12}$

Artists were not subject of selection, instead they could join the circle and the project if they felt close to this atmosphere. Things would have changed, but at that precise moment the movement was intended as a «natural form» 13 to socialize and share information. After having been a participant of the first issue of MANI, edited by Monastyrski, Zakharov realised the second one together with Victor Skersis (who at that time formed the artistic duo called SZ), inviting artists to participate with their own contributions. The experience continued with the folder Po Masterskim [Through the ateliers] that Zakharov accomplished between 1982 and 1983 with the artist Georgy Kiesewalter, collecting interviews and photographic documentations about the artists, their works and their studios in Moscow. As the previous model, Po Masterskim recollected information on active unofficial artists, but the historical reconstruction of the Moscow underground scene passed through Zakharov and Kiesewalter's personal selection this time. The two artists in the role of editors not only selected the artists but also the ways in which they presented their works. To each artist corresponded a handmade small leaflet composed of written interviews regularly done by Zakharov, who also curated and realised the typographic and photographic layout of each leaflet, while Georgy Kiesewalter took all the photographs and a handful of interviews, too. ${ }^{14}$ Every single copy of this "catalogue" consisted of twentytwo booklets, each of them characterised by different contents and graphic designs. In the leaflet that introduced the authors and the main goals of the project, Zakharov describes his position of artist and editor clarifying that he «did not try to draw conclusions and afterwords» 15 but «of course, cannot

12 Ibid.

${ }^{13}$ Monastyrski in an unpublished interview with me, recorded in June 2019 in Moscow.

14 Vadim Zakharov, "Ov avtorii", Vadim Zakharov, Georgy Kiesewalter (eds.), Po Masterkim, Samizdat, 1983.

15 Ibid. 
deny the subjectivity of the assessment in this paper». ${ }^{16} \mathrm{~A}$ few lines below, he then clearly qualifies his perspective that, as he says, come «from the position of the artist, and not from the position of an art historian or a researcher of art and in the nature of human destinies and souls». ${ }^{17}$ However he also declares: «Another, no less important, attempt is to look at the current situation in the local artistic environment, as if from the outside».18 Aiming at the creation of a catalogue that could collect in an objective way the unofficial muscovite artistic scene, the position held by the artists shifts slightly between the attempt to be objective and the awareness to be an active part of the same movement. This unclear and contradictory position could explain why there is no mention to the possible historical impact of Po Masterskim, presumably conceived more for the present than for the future. Zakharov stated that $P_{0}$ Masterskim was conceived as a survey of «the most interesting» ${ }^{19}$ unofficial artist working in Moscow at that time, because «simply put, I had a desire to look around. It seemed to me not only possible, but necessary. ${ }^{20}$

At the beginning of the 1980s, Zakharov started to collect documents, materials and artworks from exhibitions and events realized within the circle of Moscow conceptualists. These documents were stored in his private apartment, but at this time they were not organised in a proper archive and, even if Zakharov collected with the idea that it would be important for the future historicisation of the movement, he did not plan to establish a proper archive of Moscow Conceptualism. Anyway, this fact says something more of his interest in the artistic circle he was joining, an attentiveness that is also at the centre of his coeval artistic practice. Such attitude was also typical of the older Moscow conceptualists, such as Ilya Kabakov, Erik Bulatov, and Victor Pivovarov, who noted the originality of their practices in differentiating themselves from the modernist painting that was the dominant style of unofficial Soviet art scene during the 1960s and 1970s. Differently, the younger generations of Moscow Conceptualists, and especially those who started to work at the end of the 1970s, were experiencing a different environment in which institutions as well as a real audience were still lacking, but at least there was a kind of structured underground system, with exhibitions in private apartments and visits to artists' private studios. Therefore, the young inherited the inclination towards contestation but, at the same time, they shifted their attention towards the ones that could be their own masters or models inside the circle itself. Exemplary of this tendency is the action Hand

\footnotetext{
16 Ibid.

17 Ibid.

18 Ibid.

19 Ibid.

20 Ibid.
} 
Inscriptions. I made enemies (1982), in which Zakharov wrote on his right hand critical statements addressed to artists from the older generation in which Zakharov declares to Erik Bulatov: «Bulatov it turns out you are bluffing. This is dangerous today!». In this critique, there is also the quote from an important painting by Bulatov, titled Opasno that in Russian language means exactly "danger". In this reference game, he also mentions the Russian futurism manifesto Poshechina obshestvennomu vkusu [A Slap in the Face of Public Taste] published in 1912 and signed by David Burliuk, Viktor Khlebnikov, Aleksei Kruchyonykh, and Vladimir Majakovsky. Initially composed of only four actions and photographs, the work has made Zakharov the object of negative comments among the circle. A fact that led him to the decision of adding a fifth action and photograph to the series, writing on his face the sentence «I made enemies», commenting these events with these words that finally he added to the title, too.

In this collective atmosphere characterized by sharing and collision, we can find the peculiarity of the Soviet Nonconformist art, confined within private events to avoid KGB attentions as, even during the Eighties, there was a strict control over unauthorised cultural events. In this context each factor, such as interpersonal relations, trust and confidence, and a limited number of participants contributed to create a small and inner circle in which everybody could perform more than one social role: the artists could also act as critics, or audience, but also curators of the exhibition, or even the photographers of the events. The politics of reformation inaugurated with Perestroika caused an important aperture towards relations with foreign countries and it changed the cultural system allowing officially sales of artworks to foreign buyers. In 1988, the first Sotheby's auction in Moscow took place, and in the same years, artists were allowed to travel abroad so that they could attend the openings of several exhibitions in which their artworks were shown. Some residency programs in Europe also invited artists from USSR in order to show their works to the international audience. At the end of the 1980s Zakharov began to travel as an artist, too, and in 1989 he moved to Germany where he still lives. Many other artists left Moscow and relocated elsewhere especially in France, Germany and USA, looking for new working and living opportunity in the West.

In this period characterised by changes, he started to develop a more conscious approach to his archival practices. Since the beginning of the 1990s, it is common to find many references to the topic of archive in his artworks and installations that address the theme as a background thematic together with analogue topics such as the accumulation and collection of documentations. At the same time, in his works the archive appears also as an aesthetic element, when forms specifically related to archival environments, 
as folders, become elements in his exhibitions. Lastly, the archive is presented also in terms of the construction of a real archive, as activity that made the artist define and introduce himself as archivist to the audience of his exhibition, as testified in several press reviews to his exhibitions published in various magazines during the 1990s.

In 1989 it might seem plausible to date the first list of the artworks he collected that is handwritten in a notebook and is today preserved in the archive. It can be considered as a first attempt of cataloguing that report technical information such as author, title, year, dimension, and so on. It can be interpreted as an instrument to manage the relocation of the collection in Germany, but even more important is to look at the list as a sign of Zakharov's growing professionalism as archivist and collector. Since 1988, when the watershed moment of the first Sotheby's auction in Moscow happened, it was definitely established that a season of official international recognition and attention for contemporary unofficial art from USSR and Russia had started. Between cultural curiosity, exotism, and politicized views, stereotypes and labels on political dissidence and the trauma of living in USSR, artists from unofficial art became protagonists of numerous and big exhibitions, and also Zakharov participated in this wave both as artist and collector, loaning his works to institutions. For this reason, the list seems to be a necessary tool to know precisely and keep under control the collection. In the same year, another crucial event for the emergence of the artist's archival drive was the decision to buy his first video camera that he used to record events and exhibitions to which Moscow Conceptualists and artists from Russia participated. His idea was to document a transitional period and resulted in testifying the success as well as the problematics connected to the ways in which several institutions, as museums and galleries, were introducing Russian artists after these important socio-political changes. With these records, he gave birth to the video section of his archive that soon started to host several footages organised per year: at the end of 1989 the archive had 11 recordings among Germany, Austria, Italy, Russia and USA. In 1990 he added other 17 recordings, in 1991 15, and so on, with a slight reduction starting from 2000, up to 2014 when he officially closed his archive of Moscow Conceptualism.

Close to this attitude is the foundation of the publishing house Pastor Zond, as well as the conception of the artistic project and collective artwork Pastor, a magazine that he ran from 1992 to 2001 and resulted in eight issues. Based in the city of Köln, the magazine was intended as a platform, an archive that could be a meeting point where all the artists from Moscow Conceptualism were recollected, with the aim to overcome the distance that happened after many of them left USSR. Published in the Russian language, 
Pastor was a new reinterpretation in a different time and place of the Samizdat tradition. The methods of self-production and circulation were thus reproduced but with the awareness that the artist was now working in a new context and system. In those years, in fact Zakharov used computer graphic for his works, introducing a new and more contemporary style that finally overcame the Soviet typical typescript one, adding a new layer in his production. The result of his work was an object that had a different aura, and an appeal closer to the Western magazines, published by officially established publishing houses, even though he was still using the methods of selfproduction. He personally asked some artists to participate in the project, therefore to send by mail to him documents so that after having collected all these documents, he could copy them on his computer. Finally, he could print and glue all the pages together, and then he could bind the resulting magazine with a cover. The production process was developed in complete solitude and recorded on videotapes that today are collected in his video archive, too.

The topic of archive as aesthetic cipher started to affect also his personal artistic production, a thing that demonstrates a real "archive fever", quoting the French philosopher Jacques Derrida. Zakharov used the format of folder for his installation in his solo shows, and the topic of archive started to be at the core of his poetics. In 1992 he realised Aqua Sacra (Figure n.3) and in the same year were published the first exhibition reviews on daily newspaper and art magazine about his activity as artist and archivist, but this double position is presumably presented in one of his most powerful aspects in the solo show Der Letze Spaziergang durch die Elysischen Felder 1978-95 held at the Kunstverein in Köln. The artist divided the exhibition into three parts: the park, the archive and the other, a distinction that he repeated in the catalogue, in which he also published his own first text on the archive. Realising the volume in quality of book designer, he took to an extreme level his interest in mixing up his different professional skills. Nevertheless, the importance of this shift among artistic strategies was a topic that the curator of the show, Udo Kittelmann analysed in the curatorial text included in the catalogue. The latter examined the complexity of the entire exhibition project highlighting the artist's necessity to act continuous modifications of elements as a personal strategy that allowed him to explore the possible infinite connections among elements. In such mobility, Kittelman identified the main problem for an art historian who would understand and describe Zakharov's work that is structured, following the curator's words, as an "Eisberg system". With this term he called this methodology based on the complexity of stratifications, and in the coexistence of opposite poles in life and art. On this contradiction and sense of instability, Zakharov founded his idea that to deepen the knowledge of the world is it perhaps necessary to question any path, idea or 
concept of his own investigation. In the catalogue of the Russian pavilion at the Venice Biennale of 2013, dedicated to his installation Danaë that occupied all the entire structure, and curated also by Kittelmann, he said:

«My system is an iceberg. The part under water exists, and the part above water develops from it and depends on it. It is an organism that belongs together. [...] A work becomes interesting when it exhibits many layers. One can perhaps understand some of them, but not the rest ${ }^{21}$.

Danaë itself presented a multi-layered structure composed by new works and by the re-use of elements from previous artworks, as the folder coming out from a wall installed in the lower part of the project inside the cave. This element clearly recalls the basis of the artwork Fountain aqua sacra he did in 1992, in which the archival element is integrated in a functioning fountain.

Going back to the historical route of this text, an important evolution for Zakharov's interest in archives happened in the period that goes from the beginning of the 2000s up to 2014, when he developed in many ways a more personal, sometimes paranoid, reflection on the role and the use of archive as topic and material.

In 2003, he conceived the big installation History of Russian Art from the Avant-garde to the Moscow Conceptual School for the exhibition Berlin-Moskau / Moskau-Berlin 1950-2000 that took place in the two capitals in 2003 and 2004, visible in Figure n.4. It reproduces five realistic folders in increased dimensions and, above all, it leads the spectator into experimenting strategies typical of archival practice. As stated by the artist, the artwork represents «an author's subjective classification of Russian contemporary art, staged as a bureaucratic drama» ${ }^{22}$ : if the front of every folder has an informational label that refers to important artistic movements that occurred in Russia, the back is open to let the public enter inside, as shown in Figure n.5. The three central folders contain a selection of artworks related to the artistic movements declared on the label, while the first folder dedicated to the Russian avantgarde is closed to the public, who can only hear the recorded sound of somebody snoring. In a different way, the folder devoted to the Moscow Conceptual School, that in his label has also the word "Archive", introduces the public to an archive created by Vadim Zakharov. It was composed with folders filled with information on artists and topics of this movement, that he realised precisely for this work. Basically, the observer falls into a myse en abime that reveals the intricate structure of the work, based on a game of references

21 Vadim Zakharov, Udo Kittelmann and Stella Kesaeva (eds.), Vadim Zakharov: Danaë (Ostfildern: Hatje Cantz, 2013), p.68.

22 Vadim Zakharov, "The history of Russian Art from the Russian Avantgarde to the Moscow Conceptual School", Teresa Mavica, Vadim Zakharov (eds.), Vadim Zakharov 25 let na odnoj stranitse. Vadim Zakharov 25 years on one page, (Moscow: Interros, 2006), p. 242. 
that also quotes the real archive, including his practice as archivist, not to mention his artistic activity. To an extended view, it also permits one to think of all the previous experiences that had archival connotation as MANI, Po Masterskim and Pastor. In an exhibition project devoted to the investigation of relationships between Germany and Russia, he presented an artwork that combined the archive and Art History, both intended as vessels in which only some elements can enter, following processes of selection and classification that derive from cultural model. Each selection requires the exclusion of many other elements. With this association he pointed at the contradiction that lies at the base of the assumed objectivity of a system, that base his legitimation on the invention and abuse of general labels, and the reality, that seems to suggest the contrary, i.e. that it is possible to enter into the folds of a system only through arbitrarily subjective criteria. The same title given to the work indicated the idea of an official "History of Russian art" as a summa of an objective research, but in fact, the artist himself declared that it was the result of personal selection. Clearly, the titles of the folders represent artistic movement that did not cover the totality of experiences that happened during the twentieth century. Indeed, the artist voluntarily excluded, for instance, the generation of artists that emerged in the 1990s, among them Kulik, too, because, in his words, the individualism of their research did not permit him to present this reality as a solid and structured movement. Instead of presenting his personal research in the exhibition, he chose to be part of the Moscow Conceptualist school, demonstrating, many years after the group split, the centrality of the context of his provenience and formation, and how important was still the sense of belonging to this past for the creation of his identity. However, even if he was acting as the archivist and as an historian, his "personal" selection demonstrates that he was following the artistic trends and waves yet received, absorbed and legitimated by the international art system.In 2003 and 2009, Zakharov also played the role of curator for the exhibitions Moskauer Moskauer Konzeptualismus. Sammlung Haralampi G. Oroschakoffund Sammlung-Verlag-Archiv Vadim Zakharov and Kollektsija i arkhiv Vadima Zakharova that showed some works from his collection and his archive of Moscow Conceptualism, respectively held at Kupferstichkabinett in Berlin and at NCCA in Moscow. In the catalogues issued for the events, the artist published two texts that point to his poetic, presenting for the first time his ambivalent relation to his archivist alter ego. As the title reveals, Shiva's method: archive, collection, publishing house and artist is a metaphor for his hyperactivity that starts with a short reconstruction of the archival tendencies in contemporary art. Published for the first time in 2004 in the catalogue of the Berlin exhibition, the text continues with his own personal history, and with comments on artworks and experiences connected to the archival practices but with a literary tone alternating paranoid comments, as «I don't need 
compassion or pity. I alone am responsible for my stupidity and my empty pockets. My ambitions as an artist are on a par with the avarice of the collector, the bureaucratism of the archivist, and the aloofness of the publisher» 23 and «It is important to remember that any growing archive or collection will, sooner or later, bury its collector. The archive - an assassin. The collection - a pickpocket. The publisher - an undertaker. The artist is always the victim. But sometimes the victim kills the Archive». 24 The conception of the archive as a living organism that can have an independent life and can attack his creator is continued in Archive as an alien. Here Zakharov focused on the role of the archive in contemporary art, an era characterised by the progressive loss of importance of exhibitions, and the problematic role of curators, denouncing their working attitudes more and more connected to the market than to culture. An excerpt from the text says: «It is important to be responsible for the quality of the information. In any event, I, as an artist-archivist, can and must, while creating my photo and video archives, be responsible for them if the times demand it, entering into a new, active dialogue with the Archive of culture and offering co-authorial arrangements to curators and dealers». ${ }^{25}$

The inclination to the end and death flowed in his big installation Postscript after RIP: A Video Archive of Moscow Artists' Exhibitions (1989-2014) displayed at Garage Museum of Contemporary Art in Moscow, in 2015, shown in Figure n.6. With this artwork, Zakharov publicly declared the end of his activity as archivist staging the death of the archive through the construction of a cemetery where sculptural structures in the shapes of folders stood for coffins. Through the folder ring the audience could watch hours and hours of video he recorded during the exhibitions of Russian artists, as visible in Figure n.7. In the critical text accompanying the catalogue, Sven Spieker defines Zakharov's dualism with the specific terms of "archiviophilia" and "archiviophobia", as the two tendencies between the positive and the negative attitude, with which he identifies two opposite and complementary souls that, intermittently, animated his archival practice. ${ }^{26}$ Each folder contains one entire year of recordings, and thus show another aspects of his dichotomy as Zakharov sometimes recorded in the more professional and objective way as

\footnotetext{
23 Vadim Zakharov, "Shiva's method: archive, collection, publishing house and artist", Vadim Zakharov, Alina Fedorovich (eds.), Kollektsija i Arkhiv Vadima Zakharova. Collection and Archive by Vadim Zakharov (Moscow and Köln: NCCA and Pastor Zond Edition, 2009), p. 16.

24 Vadim Zakharov, "Shiva's method: archive, collection, publishing house and artist", pp. 16-17.

25 Vadim Zakharov, "The Archive as an Alien", Alla Rosenfeld (eds.), Moscow Conceptualism in Context, (New Brunswick: Zimmerli Art Museum at Rutgers University; Munich and London: Prestel, 2011), p. 363.

${ }^{26}$ Sven Spieker "A Double Archival Imperative in Vadim Zakharov's Work", Sasha Obukhova (ed.), Vadim Zakharov. Postscript after RIP: A Video Archive of Moscow Artists' Exhibitions (19892014) (Moscow, Garage museum, 2015), pp. 8-11.
} 
possible to him, sometimes in the most amateurish way. The resulting images could therefore represent another level in the double identity of Zakharov, divided between the Moscow tradition made of autarchy and self-production, and the immersion in the glossy style more typical of the Western lifestyle. An opposition that also recalls the phrases that Zakharov wrote is the catalogue of the exhibition: «It's time to admit that any lifelong project of preserving all things important eventually becomes meaningless when it turns into a routine». ${ }^{27}$ The desire sometimes leaves his place to the tiredness, and the feeling of obligation to one big project as the establishment of an archive and the choice to follow this new institution by himself, during his private time. In the same text he continues theorising the idea of the archive as a killer: «The "killer archive", as I have come to call it, was controlling my life and my thoughts. I became tired of running away and hiding from it in my bathroom and under my bed».28

The bureaucratic aspects, practicality and usefulness of the archive completely disappeared in the name of an absolute exhaustion that he mixes also with anxiety. The fear of an artist that, afraid of being persecuted by the dedication and obligation to his archive, decides to kill his relation with the archive, closing it and selling one part of his video archive in an edition of $1 / 4$ to the Museum Garage. A gesture that sounds like the acceptance that finally time has come to accept the historical value of the collected item, and the changed scenario would open another to another aspect. Since 2012 the same institution started an acquisition policy concerning artists' archives, with the aim of collecting important documents for the history of Russian culture and art, that otherwise would risk to disappear or to be acquired by other countries. This choice tells a lot about the condition of Russian art history that is still a quite recent discipline due to its socio-cultural and political history. The lack of institutions until the 1990s, apart from the official ones, which unluckily record only information on official Soviet art, still affect the knowledge of this artistic scene. Especially because the history of institutions, even in the capital Moscow, was important but not easy, for economic and cultural limitations that continued for decades. Meanwhile, many artists acted differentiated roles, as Zakharov, playing a role in the construction of their own Art History, and hopefully to the diffusion of their culture and art, or Kulik performing as a dog. Nevertheless, the discomfort felt by several artists, before for being marginal in their local areas, was soon transformed into the concern for feeling marginal and misunderstood even if working internationally. The animality as metaphor of the struggle to be part of a wider

27 Vadim Zakharov, "P.S", Sasha Obukhova (ed.), Vadim Zakharov. Postscript after RIP: A Video Archive of Moscow Artists' Exhibitions (1989-2014) (Moscow, Garage museum, 2015), p. 122. 28 Vadim Zakharov, “P.S”, p. 122. 
and international scene, shown at the beginning of the article, thus seems to be just one of several responses given by artists living the fight that still impacted the so-called art from Eastern Europe. Today it is therefore primary to understand the role played by artists, writing articles for magazines and catalogues, creating collaborative projects based on the investigation of identities in a transitional period, reflecting and creating artwork about the historicisation of their own work in decades that saw the growing emergence of the Global Art History and of the hypertrophy of images. In his text The archive as alien Zakharov appears to find his personal solution highlighting the role of artists as well as in the use of archives as a strategy and a source to give roots to the development of art that could stay also in the future. «The artist's personal responsibility, and the curators' rejection of the positivistic idea of utilizing the Archive of culture as a mechanism for achieving their goals, could become a turning point in the understanding of how and toward what goals we aspire in art, and what will remain after us». ${ }^{29}$

29 Vadim Zakharov, “The Archive as an Alien”, p. 363. 


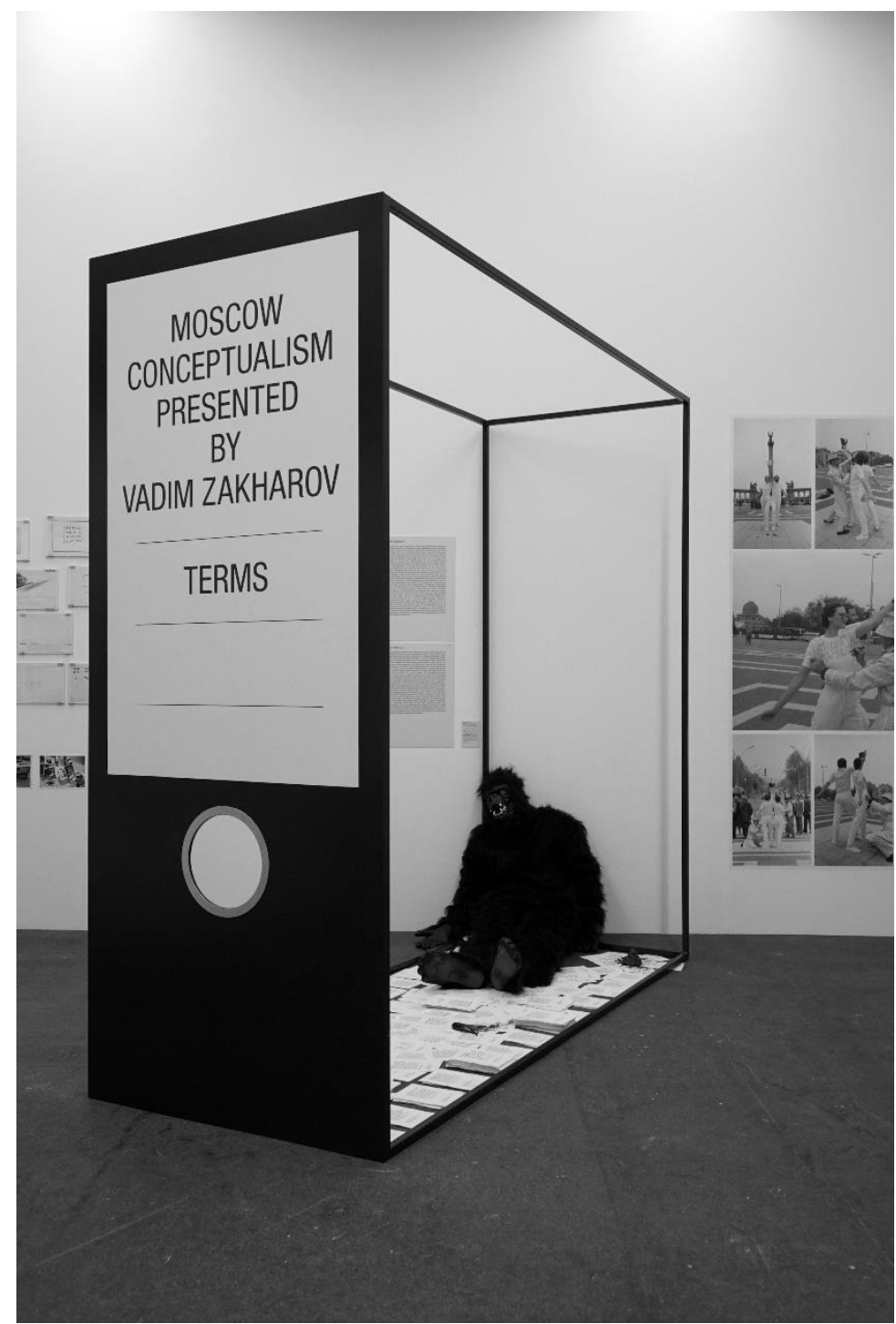

Figure 1, Vadim Zakharov, Moscow conceptualism presented by Vadim Zakharov. Terms, 2018. Exhibition view "Hello World. Revision einer Sammlung" at Hamburger Bahnhof, Berlin. Photo Alessandra Franetovich. Courtesy the artist. 


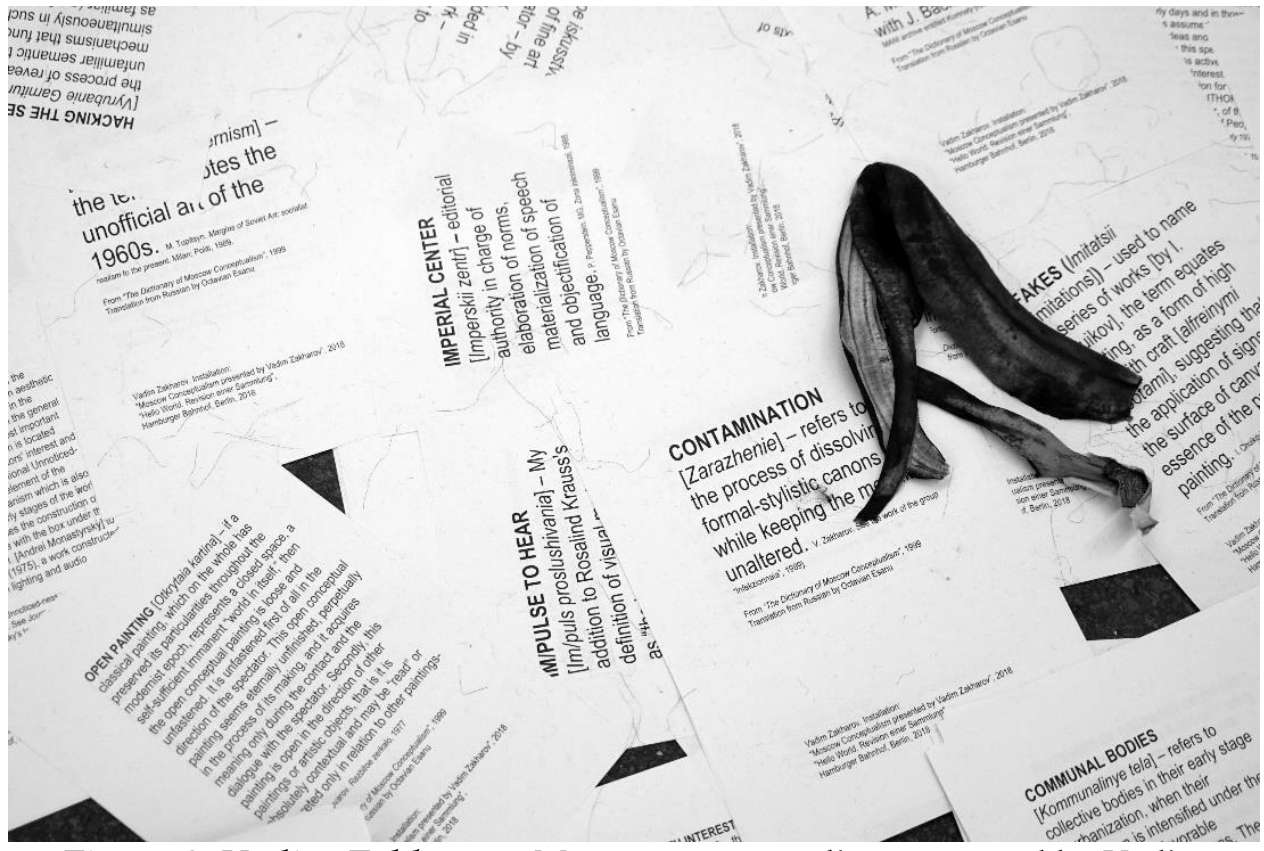

Figure 2, Vadim Zakharov, Moscow conceptualism presented by Vadim Zakharov. Terms, 2018. Exhibition view "Hello World. Revision einer Sammlung", in Hamburger Bahnhof, Berlin. Photo Alessandra Franetovich. Courtesy the artist. 


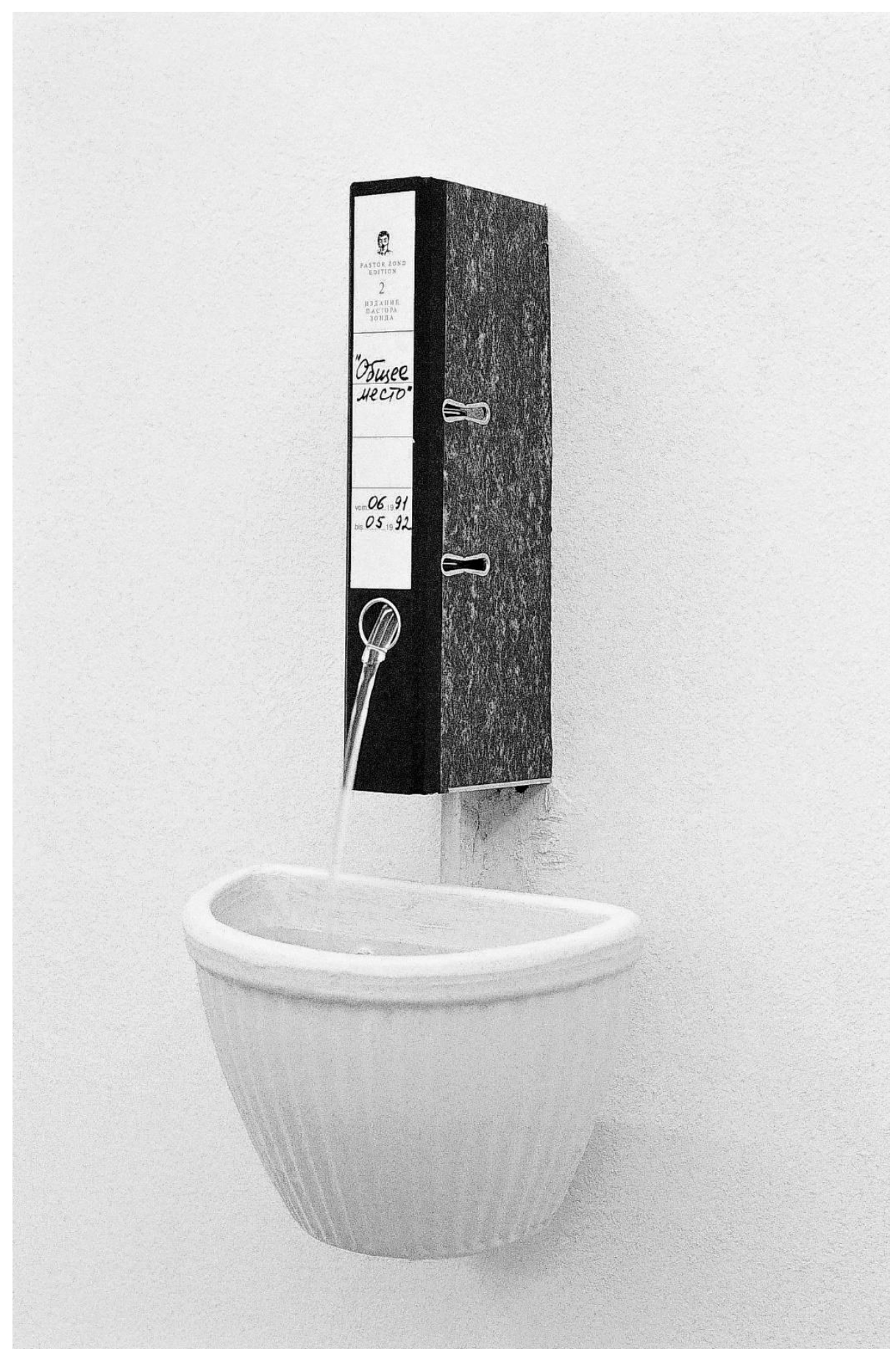

Figure 3, Vadim Zakharov, Fountain. Acqua Sacra, 1992. Courtesy the artist. 


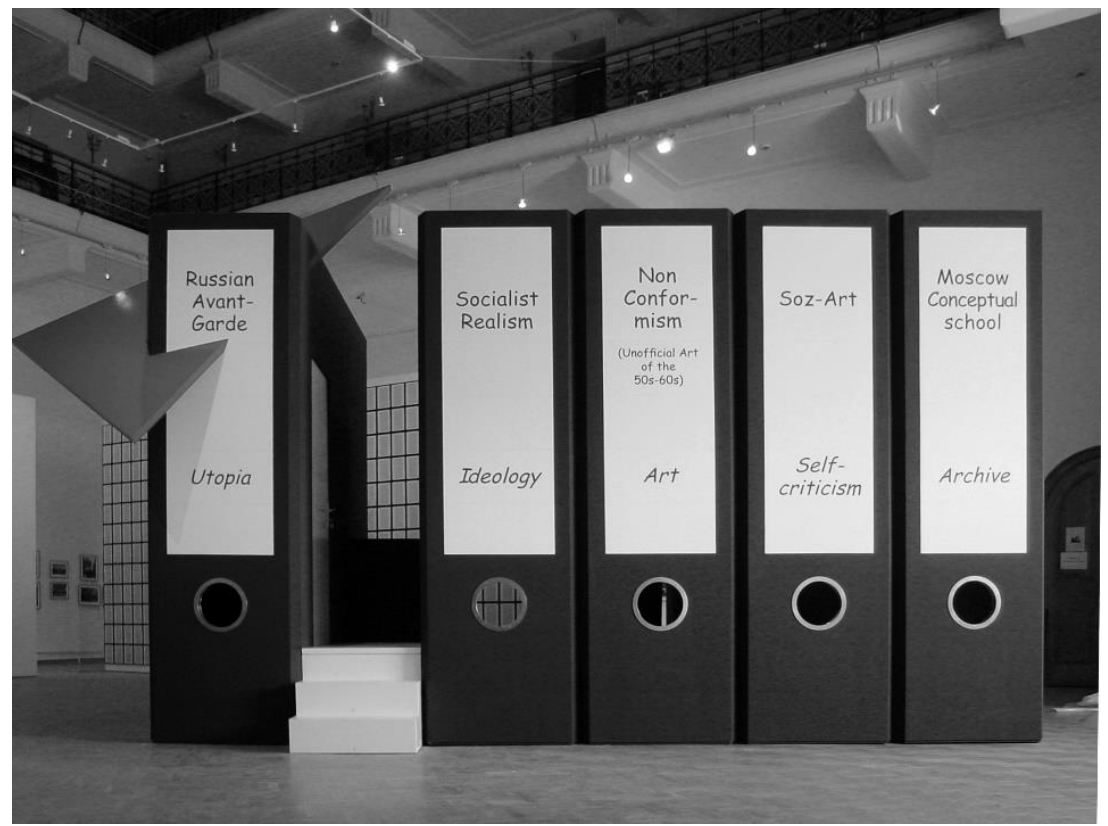

Figure 4, Vadim Zakharov, History of Russian art from the avant-garde to the Moscow conceptual school, 2003. MMK, Museum für Moderne Kunst Frankfurt am Main. Courtesy the artist.

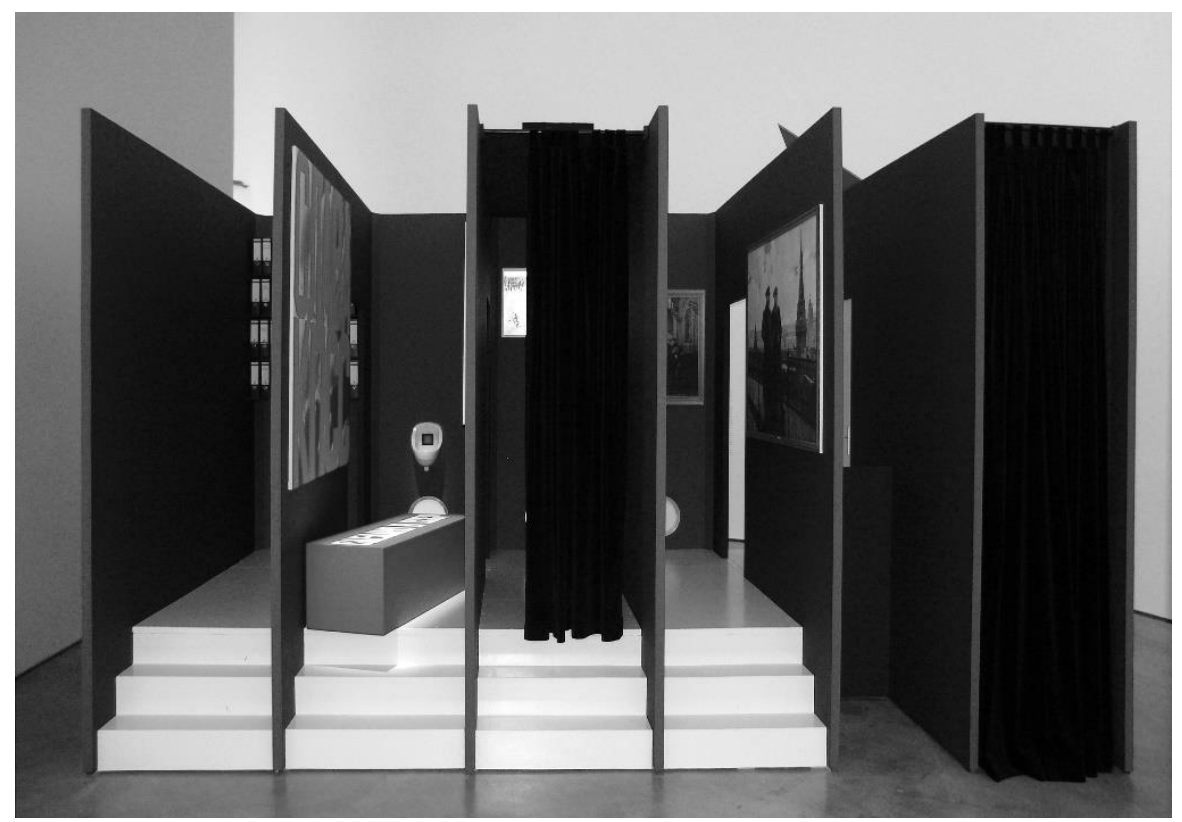

Figure 5, Vadim Zakharov, History of Russian art from the avant-garde to the Moscow conceptual school, 2003. MMK, Museum für Moderne Kunst Frankfurt am Main. Courtesy the artist. 


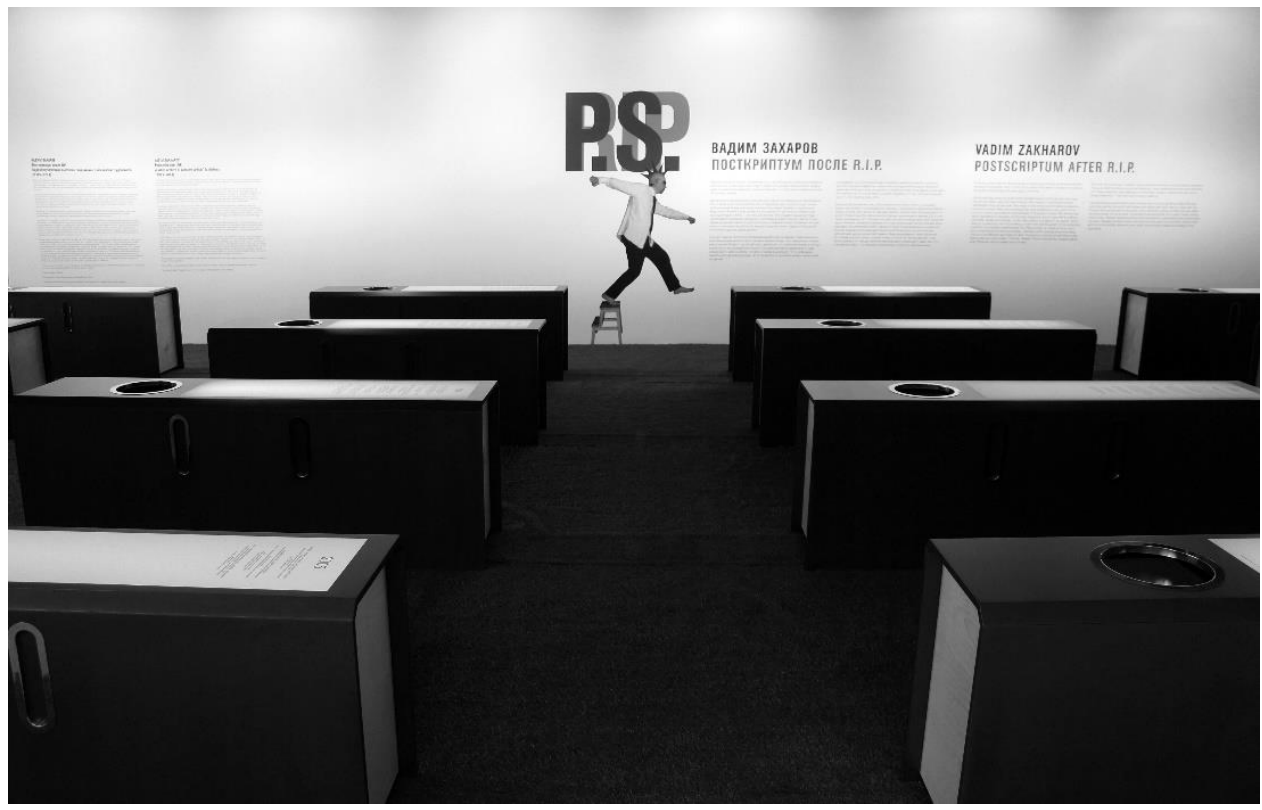

Figure 6, Vadim Zakharov, Postscript after R.I.P, 2015. Exhibition view of the installation presented at Garage Museum, Moscow. Courtesy the artist.

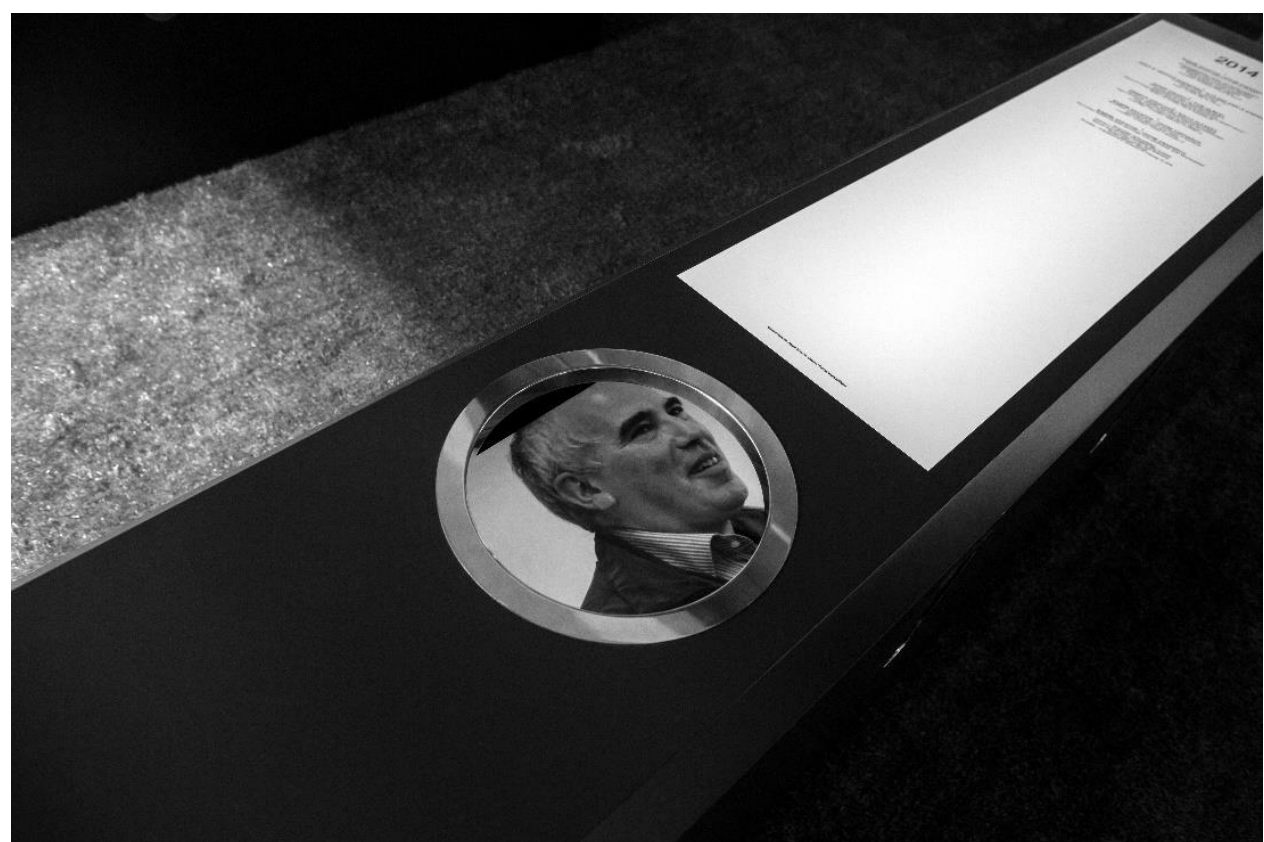

Figure 7, Vadim Zakharov, Postscript after R.I.P, 2015. Exhibition view of the installation presented at Garage Museum, Moscow. Courtesy the artist. 